Geo-Marine Letters

Volume 26, Number 6 / December, 2006 : 311-315

http://dx.doi.org/10.1007/s00367-006-0042-2

(c)2006 Springer Science+Business Media

The original publication is available at http://www.springerlink.com
Archimer, archive institutionnelle de l'Ifremer http://www. ffremer.fr/docelecl

\title{
The French Atlantic margin and deep-sea submarine systems
}

\author{
J.-F. Bourillet ${ }^{1}{ }^{\star}$, S. Zaragosi ${ }^{2}$ and T. Mulder $^{2}$
}

(1) Laboratoire Environnements Sédimentaires, IFREMER, Géosciences Marines, B.P. 70, 29280 Plouzané Cedex, France

(2) Département de Géologie et Océanographie, UMR 5805 EPOC, Université de Bordeaux I, 33405 Talence

Cedex, France

*: Corresponding author : jfb@ifremer.fr

\begin{abstract}
:
The sedimentary infill of the Bay of Biscay off Ireland, UK, France and Spain took place in four phases. The last one (35 Ma to present) is characterised by gravitational, pelagic, contouritic and glacigenic processes leading to the setup of three deep sea systems. To the North, the Celtic and Armorican fans are fed by a "canyon-dominated" margin and its connection with the "Manche" palaeoriver, which drained a large area of western Europe. To the South, the Cap-Ferret fan results from the evolution of a "tectonic-dominated" margin and the erosion of the Pyrenee mountains.
\end{abstract}




\title{
The French Atlantic margin and the deep sea submarine systems
}

\author{
J.-F. Bourillet ${ }^{1}$, S. Zaragosi ${ }^{2}$ et T. Mulder ${ }^{2}$ \\ ${ }^{1}$ IFREMER, Géosciences Marines, Laboratoire Environnements Sédimentaires, BP70, 29280 \\ Plouzané Cedex, France jfb@ifremer.fr \\ ${ }^{2}$ Université de Bordeaux I, Département de Géologie et Océanographie, UMR 5805 EPOC, \\ 33405 Talence Cedex, France
}

\begin{abstract}
The sedimentary infill of the Bay of Biscay off Ireland, UK, France and Spain took place in four phases. The last one (35 Ma to present) is characterised by gravitational, pelagic, contouritic and glacigenic processes leading to the set up of three deep sea systems. To the North, the Celtic and Armorican fans are fed by a « canyon dominated » margin and its connection with the «Manche » palaeoriver which drained a large area of western Europe. To the South, the Cap-Ferret fan results from the evolution of a « tectonic dominated » margin and the erosion of the Pyrenee mountains.
\end{abstract}

\section{Geological setting}

The French Northeast Atlantic margin extends on the northern passive margin of the Bay of Biscay over more than $1,000 \mathrm{~km}$. Its history started with the opening of the Bay of Biscay. Conversely to the contemporaneous Atlantic rift, the opening stopped in this part of the margin. Basement seamounts represent the fossil rift that split the Bay into a wide northern basin and a narrow southern basin. The infill of these basins took place in four phases: (1) syn-rift and black shale deposition during the opening phase (140 to $80 \mathrm{Ma}$ ), (2) syn-orogenic deposition during the Pyrenean compression (80 to $35 \mathrm{Ma}$ ) and (3) posttectonic deposition (Thinon, 1999). The late sedimentation phase (4) is characterised by the strong activity of canyons. It homogenised the seafloor morphology of the continental rise. The sedimentary processes are numerous (downslope gravity processes, pelagic, contouritic and glacigenic sedimentations) and lead to the set up of several deep sea clastic systems.

\section{Morphology of deep sea systems}

The French Atlantic margin can be divided in three parts : the Celtic margin in the North and the Armorican margin and the Aquitaine margin in the south (Fig. 1). But the major relief is the continental slope with a "canyon dominated" slope (Celtic and Armorican) and a "tectonic dominated" slope (Aquitaine).

\section{Celtic and Armorican margins}

The Celtic margin extends from Goban Spur to the Berthois Spur. The continental shelf is oriented $\mathrm{N} 115^{\circ}$, wider than $250 \mathrm{~km}$ but especially delimited by a notched coast with two large indentations: the Irish Sea and the English Channel. The South part of the Celtic outer shelf is characterized by the presence of sand banks, 40-180 km long, 5-10 $\mathrm{km}$ wide and $40 \mathrm{~m}$ high. These banks are roughly oriented $\mathrm{N} 30^{\circ}$, i.e. along the present tide current direction. For some authors, they represent the relics of the paleodelta of the Manche River (Lericolais 1997) when for others (Reynaud et al. 1999; Marsset et al. 1999) they could be purely fossil tidal sand banks. Below the sandbanks, a network of infilled palaeovalleys attests to a direct link between the slope and the palaeoriver "Manche" with a likely Pliocene age for the valley incision (Bourillet et al. 2003; GraciaGaray et al. 2004). 
The Armorican margin extends from Berthois Spur to Conti Spur. The Armorican continental shelf is up to $200 \mathrm{~km}$ wide with a shelf break oriented N140 ${ }^{\circ}$. Palaeovalleys are very developed up to isobaths 40-70 m (Menier, 2004 ; Chaumillon and Weber, in press) when only few of them reach the shelfbreak (Pinot, 1974 ; Bourillet et al., 2005).

The morphology of the continental slope (Fig. 1) is characterized by spurs and canyons organized in submarine drainage basins (Bourillet and Lericolais, 2003). The southern Celtic margin includes two major drainage basins: (1) the Grande Sole drainage basin located southward of the Irish Sea and limited by the Austell Spur and the Brenot Spur; (2) the Petite Sole drainage basin located seaward of the Western Approaches and limited by the Brenot Spur and the Berthois Spur. Both drainage areas fed the Celtic deep sea system thanks to the Whittard and Shamrock canyons. The Berthois Spur continues seaward by the Meriadzek Terrace and the Trevelyan Escarpment. These two morphological features are oriented $\mathrm{N} 105^{\circ}$ that is consistent with the general structural direction corresponding to the opening of the Bay of Biscay. Between the Berthois Spur and the Delesse Spur, La Chapelle drainage basin fed the Armorican deep sea system thanks to Blackmud and Guilcher canyons. The Meriadzek Terrace and the Trevelyan Escarpment form a deep morphological relief splitting the sedimentary supplies from the shelf either to the West toward the Celtic system or to the East toward the Armorican system.

The discovery of these deep-sea turbidite systems is recent. The initial works suggesting the presence of a clastic system off Celtic and Armorican slope are those of Auffret (1983).

Between the Delesse Spur and the Conti Spur, four additional drainage basins can be identified and are all fed by canyons dissecting the continental slope and rise (1) the western Brittany drainage basin, (2) the southern Brittany drainage basin, (3) the Gascogne drainage basin, and (4) the Rochebonne drainage basin. No significant deepsea fans are located at the mouth of the lower valleys but only small channel-levee complexes, slump or small lobes.

\section{Aquitaine margin}

The Aquitaine margin extends from Capbreton Canyon to Conti Spur with a narrow $(70 \mathrm{~km})$ subsident shelf. The Aquitaine Shelf is the continuation of the Armorican Shelf (Fig. 1). It is $60 \mathrm{~km}$ wide and is limited in the South by the Capbreton Canyon. The Gironde palaeovalley is poorly developed and tapers at isobath $70 \mathrm{~m}$ (Lericolais et al., 2001) when ante-Pliocene palaeovalleys reached the head of Cap-Ferret Canyon (Bellec, 2003).

The Aquitaine continental slope is smooth and is extended by the marginal Landes Plateau dipping gently westward. It is bordered by steep slopes that form the south flank of Cap-Ferret Canyon in the North, Capbreton Canyon in the South, and Llanes Canyon in the West. In the south, Capbreton Canyon is bordered by the basco-cantabrique continental margin with very steep slopes. It is an atypical canyon for the Bay of Biscay with a meandering course and a head directly connected to the fluvial river (Cirac et al. 2001). Even during highstands, Capbreton Canyon behaved as during lowstand periods.

The only deep-sea clastic system in this southern part of the Bay is the Cap-Ferret system. It is supplied by the canyons and channels that drain the Landes drainage basin and part of north-east Spanish continental slope thanks to the Capbreton Canyon and the 
S-N Llanes Canyon. These two canyons join downward the prolongation of the CapFerret Canyon.

The sedimentary accumulation on the Cap-Ferret has been identified on the bathymetric map of Berthois and Equer (1974). During the late 1970', several cruises with bathymetric, photographic, THR and HR seismic surveys and Kullenberg cores allowed to collect data on this system. These data have been synthesized by Cremer (1983). However, no recent cruises have been planned since this period and this system remains poorly known compared to those of the north part of the Bay.

\section{Tectonic, climatic and eustatic history of the margin}

In the Bay of Biscay, there is an important morphological contrast between the north and the South margin. This contrast results from the geological history including two major tectonic contexts (Derégnaucourt and Boillot 1982): (1) A phase" of crustal distension and rifting from the late Jurassic to the early Cretaceous (Sibuet et al. 2004) and (2) a phase of partial ocean closing during the Caenozoic. Since the age, the South Celtic margin is characterized by a very low subsidence rate (5-6 $\mathrm{myr}^{-1}$ ) (Bois et al. 1991).

The opening phase is at the origin of the deep part of the Bay and its margins. The relics of this phase is clearly visible on the deep-structure of the margin with the presence of tilted blocks separated by listric faults and forming a typical half-graben morphology (Boillot et al. 1972; 1974) filled with cretaceous sediments and with the presence of isolated knolls (Gascogne) and seamounts (Biscay, Charcot, Armorican). The closing phase generated the shortening of the North Spanish margin bounded by the north Spanish marginal overthrust. The Eocene compressive phase and the subsequent Oligocene inversion (Pyrenean phases) generated the surrection of several reliefs such as the Trevelyan Escarpment and the Gascogne Knoll. They represent the limit between thinned continental crust and oceanic crust (Thinon 1999).

The sedimentary history of the Celtic and Armorican turbidite systems began after the maximum inversion of the Early Miocene marked by a hiatus on DSDP well 400 (Droz et al. 1999; 2003). Above this unconformity, the history of the systems is characterised by the deposition of three sediment units separated by minor unconformities. These units correspond to three phases of the system evolution:

(1): Miocene and (2) Pliocene phases showing a basinward progradation of the system with frequent channel shifting. The system is mainly fed by the Manche palaeoriver with a high coarse particle load. Regional debris flows occurred during the Pliocene.

(3) Quaternary phase with a feeding from the Irish Sea with a more important fine particle load generating a more permanent channel-levee system.

A particular feature of the Armorican and Celtic systems is their recent (LGM to late Holocene) turbidite activity. Turbidity currents on these systems were mainly active during the relative sea-level lowstand (Zaragosi 2001). Sediments were supplied by the Manche paleoriver system (Lericolais 1997; Bourillet and Lericolais 2003) which drained the major rivers of the western Europe such as Rhine, Seine, and Thames, and by the British ice sheet. The direct influence of the British ice sheet and Manche Paleoriver on the deep-sea clastic sedimentation ended during the early Holocene (between 10 and 8.7 ka BP). However, coarse-grained sporadic turbiditic activity has been recognised during the upper Holocene due to the reworking of sand dunes at the shelf break by hydrodynamic processes such as swell, storm waves, tidal currents or internal waves (Zaragosi 2001). 
The turbidite deposition of the Cap-Ferret system began during the upper Eocene, after the Eocene tectonic phase (Cremer 1983). Clastic sediments are trapped in the Parentis Basin (below the Aquitaine shelf and the Landes Plateau) and deposition in the CapFerret graben is low. Only distal turbidites transported by the Capbreton and Llanes canyons reach this area.

From upper Oligocene to lower Miocene, the north Spanish overthrust is filled. An important part of clastic sediment is still trapped in the Parentis Basin but load is sufficient in the Cap-Ferret Graben to induce the formation of a channel-levee system. This system was fed by the Cap-Ferret canyon.

From Middle Miocene, the sea-level highstand prevents high turbiditic activity in the channel-levee system. Levee aggrades by spilling of muddy turbidity currents originating from the Capbreton and Llanes canyons.

From Upper Miocene, sea-level lowering induces an increase of the terrigenous load, flowing through an incised network on the north Aquitaine shelf break (Bellec, 2003). Westward slope progradation intensifies and simultaneously, turbidite activity increases. The Plio-Pleistocene is the time of appearance of the distal Cap-Ferret system and specially the northern levee. The climate changes. It passes from a subtropical climate during Caenozoic to an alternation of glacial (cold and dry) to interglacial (wet and temperate) during Quaternary. The variations generate a reworking of the continental deposits, a rapid margin progradation and frequent gravity processes at the origin of the system.

\section{References}

Auffret GA (1983) Dynamique sédimentaire de la marge continentale celtique : évolution Cénozoïque-spécificité du Pléistocène supérieur et de l'Holocène. Doctorat d'état, Univ. Bordeaux I, France, $335 \mathrm{p}$

Bellec V (2003) Evolution morphostructurale et morphosédimentaire de la plateforme aquitaine depuis le Néogène. Thèse Géologie Marine, Université Bordeaux I, $294 \mathrm{pp}$.

Berthois L, Equer DP (1974) Carte bathymétrique du Golfe de Gascogne. CNEXO, Best.

Boillot G, Dupeuble PA, Hennequin I (1972) Le plateau continental basque: stratigraphie, structure et relation avec le canyon de Capbreton. C. R. Acad. Sci. Paris, Série D 274:1147-1150

Boillot G, Dupeuble PA, Hennequin-Marchand I, Lamboy M, Lepretre J-P, Musellec P (1974) Le rôle des décrochements "tardi-hercyniens" dans l'évolution structurale de la marge continentale et dans la localisation des grands canyons sous-marins à l'Ouest et au Nord de la péninsule ibérique. Rev. Géogr. Phys. Géol. Dyn. (2), XVI, (fasc. 1):75-86

Bois C, Gariel O, Mascle A and Schroeder I (1991) Les bassins sédimentaires de mer Celtique et de Manche : apport des profils sismiques SWAT. Mém. Soc Géol. Fr. 159:25-66

Bourillet J-F, Lericolais G (2003) Feeder systems of the fans. Morphology and seismic stratigraphy of the Manche Paleoriver System, Western Approaches. In: Mienert J, Weaver PPE (eds) European Margin Sediment Dynamics, Side-Scan Sonar and Seismic Images. Springer Verlag, New York:229-238

Bourillet J-F, Reynaud J-Y, Baltzer A, Zaragosi S (2003) The "Fleuve Manche": the sub-marine sedimentary features from the outer shelf to the deep-sea fans. Journal of Quaternary Science, 18:261-282

Bourillet J-F., Menier D. and Gaborit K., (2005) Architecture des sédiments quaternaires et vallées incisées de la marge sud-armoricaine. In: ASF (Editor), 10ème Congrès Français de Sédimentologie. ASF, Paris, Presqu'île de Giens, 1113 octobre 2005 , pp. 42. 
Chaumillon E and Weber N (in press). Spatial variability of modern incised valleys on the French Atlantic coast : Comparison between the Charente (Pertuis d'Antioche) and the Lay-Sèvre (Pertuis Breton) incised-valleys. SEPM Spec. Pub., Incised Valleys in time and space.

Cirac P, Bourillet J-F, Griboulard R, Normand A, Mulder T, Itsas team (2001) Le canyon de Capbreton : nouvelles approches morphostructurales et morphosédimentaires. Premiers résultats de la campagne Itsas. Comptes Rendus de l'Académie des Sciences de Paris, 332:447-455

Cremer M (1983) Approches sédimentologiques et géophysiques des accumulations turbiditiques. L'éventail profond du Cap-Ferret (Golfe de Gascogne). La série des grès d'Annot (Alpes de Haute Provence) Thèse d'état, Univ. Bordeaux 1, $344 \mathrm{p}$

Dérégnaucourt D, Boillot G (1982) Structure géologique du Golfe de Gascogne. Bull. BRGM 2: 149-178

Droz L, Auffret G, Savoye B, Bourillet J-F (1999) L'Eventail profond de la marge Celtique : stratigraphie et évolution sédimentaire. Comptes Rendus de l'Académie des Sciences de Paris, 328:173-180

Droz L, Auffret GA, Savoye B (2003) The Celtic deep-sea fan: seismic facies, architecture and stratigraphy. In: Mienert J, Weaver PPE (eds) European Margin Sediment Dynamics, Side-Scan Sonar and Seismic Images. Springer Verlag, New York:233-238

Gracia-Garay C, Le Roy P, Begot J, Bourillet J-F, Guennoc P, Thinon I, Reynaud JY (2004) Inversion cénozoique en Manche occidentale et implications sédimentaires. In: Les incisions et dépôts de la marge atlantique française depuis le néogène: états de lieux (Ed SGF-ASF), Paris, 25-26 novembre 2004, p. 8

Lericolais G (1997) Evolution plio-quaternaire du fleuve Manche. Stratigraphie et géomorphologie d'une plate-forme continentale en régime périglaciaire. Ph.D. thesis, Univ. Sci. Tech Lille, $265 \mathrm{p}$

Lericolais G, Berné S and Fenies H (2001) Seaward pinching out and internal stratigraphy of the Gironde incised valley on the shelf (Bay of Biscay). Marine Geology, 175: 183-197.

Marsset T, Tessier B, Reynaud J-Y, De Batist M, Plagnol C (1999) The Celtic Sea banks: an example of sand body analysis from very high-resolution seismic data. Marine Geology 158: 89-109

Menier D (2004) Morphologie et remplissage des vallées fossiles sud-armoricaines : apport de la stratigraphie sismique, Doctorat de l'université de Bretagne Sud, $\mathrm{n}^{\circ} 110,202$ p. ISBN : 2-914375-21-2. pp.

Pinot J-P (1974) Le précontinent Breton entre Penmarc'h, Belle-ile et l'escarpement continental, étude géomorphologique, Lannion, Impram, 256pp.

Reynaud J-Y, Tessier B, Dalrymple R, Marsset T, De Batist M, Proust JN, Bourillet J-F and Lericolais G (1999) Eustatic and hydrodynamic controls on the architecture of a deep shelf sand bank (Celtic Sea). Sedimentology 46:703-721

Sibuet J-C, Monti S, Loubrieu B, Mazé J-P, Srivastava S (2004) Carte bathymétrique de l'Atlantique nord-est et du golfe de Gascogne. Bull. Soc. Géol. Fr, t.175 (5):429-442

Thinon I (1999) Structure profonde de la Marge Nord Gascogne et du Bassin Armoricain. Ph.D. thesis Université de Bretagne Occidentale, $327 \mathrm{p}$

Zaragosi S (2001) Les systèmes turbiditiques profonds de la marge celtiquearmoricaine (Golfe de Gascogne): physiographie et évolution au cours des derniers 30000 ans. Ph.D. thesis Univ. Bordeaux 1, n02264, 291 p

\section{Acknowledgements}

Authors thank Jean-CLaude Faugères and Ferran Estrada for their helpful comments on this manuscript and the Groupe de Recherches (GDR) "Marges" for financial support. This represents Ifremer contribution and UMR CNRS 5805 EPOC contribution $\mathrm{n}^{\circ} 1585$. 
Figure 1: Physiographic features of the French Atlantic Margin of the Bay of Biscay: (1) Goban Spur, (2) Austell Spur; (3) Brenot Spur; (4) Berthois Spur; (5) Delesse Spur; (6) Bourcart Spur; (7) Conti Spur; (8) Meriadzek Terrace; (9) Gascogne Knoll; (10) Trevelyan Escarpment; (11) Whittard Canyon; (12) Shamrock Canyon; (13) Blackmud canyon; (14) Guilcher Canyon; (15) Cap-Ferret Canyon; (16) Capbreton Canyon; (17) Llanes Canyon; (18) Whittard Ridge; (19) Biscay Seamount; (20) Charcot Seamount; (21) Armoricain Seamount; (22) Landes Plateau. Isocontours, structural features from Sibuet et al. 2004. 
